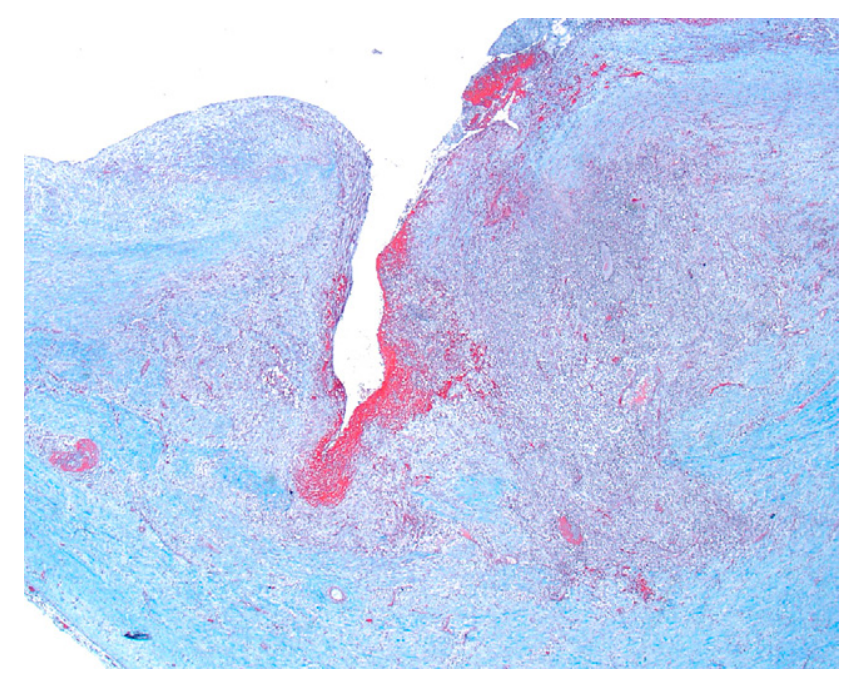

FIGURE 2. Trichrome staining of the aortic aneurysm shows red blood cell infiltration of the aortic wall. Colonies of gram-positive cocci are stained red. (Original magnification, $20 \times$.)

of a low rate of reinfection, durability, and potential for growth. ${ }^{3}$ There is concern that if the autograft were to become infected, then the optimal valve for the long-term might be wasted. An alternative would be to use an aortic homograft in what amounts to a palliative first stage of a 2-stage approach. Although offering all of the advantages of a stentless bioprosthesis, the durability of aortic homografts has been very limited in infants and young children. ${ }^{4}$ Use of a homograft would be directed at eliminating the risk of autograft reinfection, saving that valve for later implantation when infection has cleared and homograft replacement is required.
A confounding problem is the presence of ascending aortitis in conjunction with aortic valve endocarditis. This highly unusual condition requires replacement of the entire ascending aorta and thus complicates a Ross procedure because the pulmonary autograft would require prosthetic extension. Such an extension might increase the risk of reinfection, severely limit the durability of the Ross repair by virtue of a lack of growth potential, or both. Hence the aortic homograft becomes the best choice, with expectation that the Ross procedure would be performed at time of homograft failure. We predicted that the homograft would last 1 year or less based on prior experience. The primary concern for use of an autograft at the initial procedure was infection that might compromise the best long-term valve replacement option for this infant. Many of our pediatric patients undergoing the Ross procedure have had previous operations, including an aortic root replacement, and risk of reoperation in this population has been low. Aortic homograft implantation has been reported in the setting of acute aortitis in 2 children. $^{5}$

\section{References}

1. Birk E, Sharoni E, Dagan O, Gelber O, Georghiou GP, Vidne BA, et al. The Ross procedure as the surgical treatment of active aortic valve endocarditis. J Heart Valve Dis. 2004;13:73-7.

2. Kilian E, Oberhoffer M, Gulbins H, Uhlig A, Kreuzer E, Reichart B. Ten years experience in aortic valve replacement with homografts in 389 cases. J Heart Valve Dis. 2004;13:554-9.

3. Kouchoukos NT, Davila-Roman VG, Spray TL, Murphy SF, Perrillo JB. Replacement of the aortic root with a pulmonary autograft in children and young adults with aortic-valve disease. N Engl J Med. 1994;330:1-6.

4. Kaya A, Schepens MA, Morshuis WJ, Heijmen RH, Brutel de la Riviere A, Dossche KM. Valve-related events after aortic root replacement with cryopreserved aortic homografts. Ann Thorac Surg. 2005;79:1491-95.

5. Raff GW, Gray BM, Torres A Jr, Hasselman TE. Aortitis in a child with Abiotrophia defectiva endocarditis. Pediatr Infect Dis J. 2004;23:574-6.

\title{
An unusual tumor of the esophagus
}

\author{
George Rakovich, MD, Denise Ouellette, MD, and Gilles Beauchamp, MD, Montreal, Quebec, Canada
}

Carcinosarcoma of the esophagus is a very rare tumor that has both epithelial and mesenchymal (sarcomatous) components. The points of interest in the presented case are the

\footnotetext{
From the Division of Thoracic Surgery, Hôpital Maisonneuve-Rosemont, University of Montreal, Montreal, Quebec, Canada.

Disclosures: None.

Received for publication Oct 30, 2008; accepted for publication Nov 19, 2008.

Address for reprints: George Rakovich, MD, Division of Thoracic Surgery, Hôpital

Maisonneuve-Rosemont, Montreal, Quebec H1T 2M4, Canada (E-mail: george.

rakovich@umontreal.ca).

J Thorac Cardiovasc Surg 2010;139:e91-3

$0022-5223 / \$ 36.00$

Copyright (C) 2010 by The American Association for Thoracic Surgery

doi:10.1016/j.jtcvs.2008.11.075
}

osteosarcomatous nature of the mesenchymal component, as well as the early and massive recurrence after esophagectomy despite an early pathologic stage, reflecting the fastgrowing and potentially aggressive nature of these tumors.

\section{CLINICAL SUMMARY}

A 70-year-old man presented with progressive dysphagia to solid food, which he localized at the level of the midesophagus. He was an active smoker with a professional exposure to asbestos over a period of 25 years, and his medical history included hypercholesterolemia and a T3 N0 prostate cancer currently in remission after radiotherapy. Initially, he had had an acute episode of chest pain immediately after 


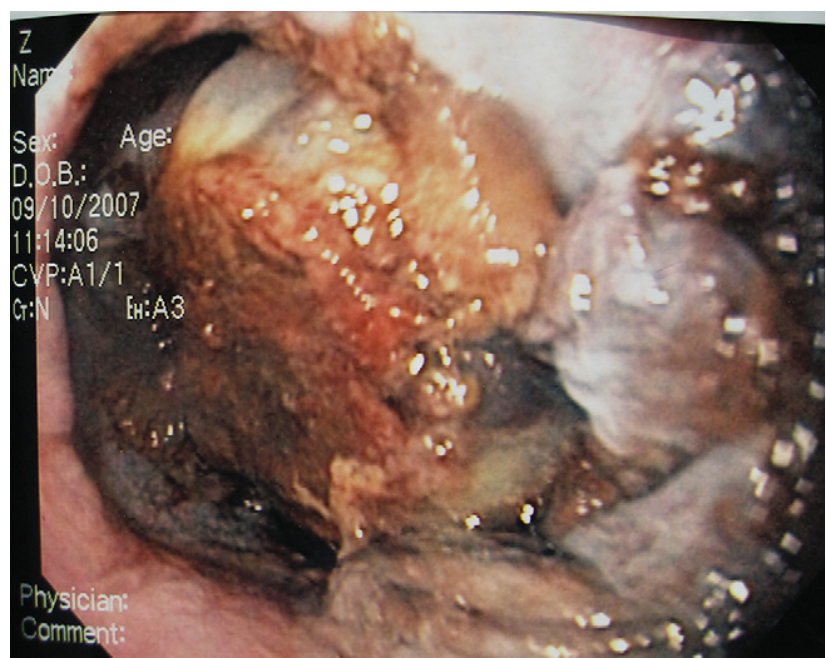

FIGURE 1. Endoscopic image showing a bulky esophageal tumor.

a meal at a Chinese restaurant; although he still described some mild pain on swallowing, this was not a predominant symptom. There were no symptoms suggestive of gastroesophageal reflux disease. Results of physical examination and routine blood work were normal.

Barium swallow showed a large $7 \times 4-\mathrm{cm}$ mass in the middle third of the esophagus that did not impede the passage of contrast medium. Endoscopy showed a very large, friable, and partially ulcerated mass in the midesophagus that allowed passage of the endoscope (Figure 1). The lesion was also visible on computed tomographic analysis as a bulky, homogenous soft tissue mass distending the esophageal lumen. There were no suspicious lymph nodes or distant metastases. The lesion had a mean standard uptake value of 19.7 on positron emission tomographic analysis. Endoscopic biopsy specimens showed a carcinosarcoma consisting of 2 components: malignant squamous and osteosarcomatous cells (Figure 2).

The patient underwent a standard 3-field esophagectomy and lymphadenectomy with gastric replacement and cervical anastomosis. A small anastomotic fistula healed with local measures, and the patient was discharged 1 month postoperatively in good condition. On histologic analysis of the operative specimen, the tumor infiltrated the submucosa, and there was 1 metastatic periesophageal lymph node (final stage T1 N1 M0).

Four months postoperatively, the patient presented with progressive weakness and a large nodule in his laparotomy scar. Fine-needle aspiration revealed neoplastic cells. Repeat computed tomographic scanning showed a massive intrathoracic and intra-abdominal recurrence. The entire lumen of the gastric transplant was obstructed by a tumor that extended into the mediastinum; there were multiple pleuropulmonary and peritoneal implants, hepatic metastases, and

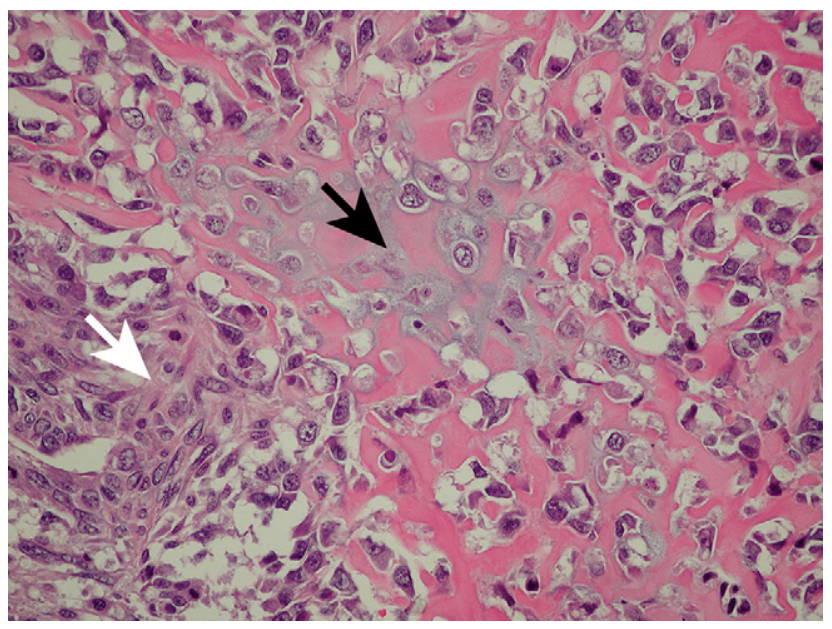

FIGURE 2. Biopsy specimen of the esophageal tumor revealing a mixed population of malignant squamous cells (white arrow) and osteosarcomatous cells (black arrow).

calcified tumor within the laparotomy scar, as noted on physical examination. The metastases contained areas of calcification that were consistent with the osteosarcomatous component of the tumor (Figure 3). The patient died within a few weeks.

\section{DISCUSSION}

Carcinosarcoma of the esophagus is rare and represents less than $2 \%$ of esophageal tumors. ${ }^{1}$ It tends to occur predominantly in middle-aged men with a history of tobacco and alcohol use. ${ }^{2,3}$ Although the term pseudosarcoma has previously been reserved for tumors in which an underlying epithelial malignancy is apparently associated with a benign mesenchymal reaction, it has become apparent that both cell populations can metastasize, and thus the term carcinosarcoma is generally used when malignant cells of both epithelial and mesenchymal origin coexist

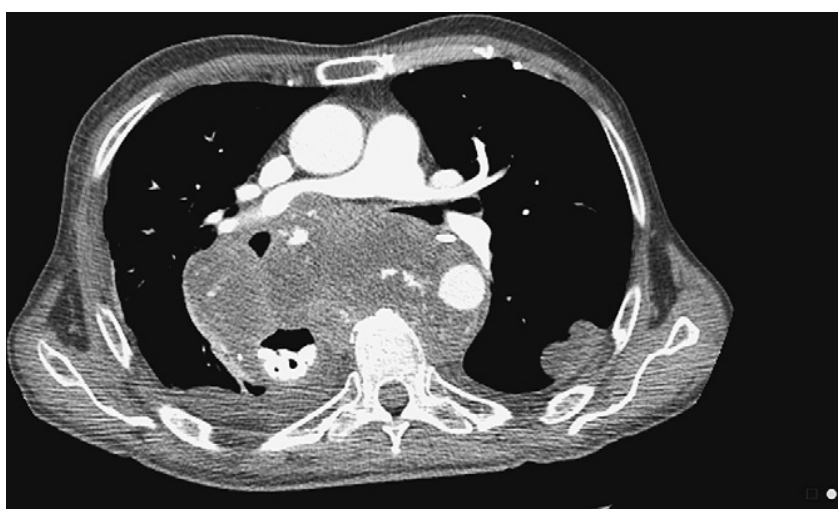

FIGURE 3. Computed tomographic image showing massive mediastinal recurrence containing calcifications caused by the osteosarcomatous component of the tumor. 
within the same tumor. ${ }^{2}$ It is generally accepted that these tumors originate as a primary epithelial malignancy from which a subset of cells then undergoes dedifferentiation into sarcomatous cells. ${ }^{1,2}$ This theory is supported by the frequent finding of a transition zone between the 2 cell populations. ${ }^{2,4}$ Previous theories of 2 simultaneously occurring malignancies (collision tumor) or a common origin from a single pleomorphic cell population have fallen out of favor. ${ }^{2}$

The epithelial component is usually squamous cell carcinoma, but adenocarcinoma can also occur. ${ }^{4}$ Fibrosarcoma is the most common sarcomatous component, although rhabdomyosarcoma, chondrosarcoma, and osteosarcoma (as occurred in our patient) have also been described. ${ }^{2,4}$ The sarcomatous cells stain for vimentin, whereas the epithelial cells stain for cytokeratin, ${ }^{4}$ although it has been reported that the sarcomatous cells might stain for cytokeratin and the epithelial cells for vimentin. ${ }^{4}$ Importantly, results of S100 protein staining are negative, thus differentiating carcinosarcoma from stromal tumor and an important diagnostic consideration. $^{3}$

Clinically, carcinosarcomas are characterized by short doubling time (around 2 months) and rapid growth. ${ }^{1}$ They are typically large at presentation (mean, 6-7 cm) and polypoid. ${ }^{2}$ Oat cell carcinoma, squamous cell carcinoma, and adenocarcinoma might also present as bulky polypoid tumors of the esophagus, although much more rarely. ${ }^{5}$ Endoscopic biopsy specimens show only the epithelial component in close to two thirds of cases. ${ }^{2}$ In spite of their propensity to cause symptoms earlier because of their large size and the fact that more than $80 \%$ of tumors are limited to the submucosa or muscularis propria at presentation, ${ }^{2,4,5}$ these tumors might behave aggressively, and thus radical resection in the form of esophagectomy is advocated. ${ }^{1,2}$ Local resection through an esophagotomy has been described in frail patients thought to represent a high operative risk, with occasional long-term survival. ${ }^{2}$ Chemotherapy and radiotherapy have rarely been reported, and their efficacy is unclear. ${ }^{2}$ Long-term prognosis is thought to be similar to that of pure squamous cell carcinoma of the esophagus. ${ }^{5}$

\section{References}

1. Hung JJ, Li AF, Liu JS, Lin YS, Hsu WH. Esophageal Carcinosarcoma with basaloid squamous cell carcinoma and osteosarcoma. Ann Thorac Surg. 2008;85:1102-04.

2. Iascone C, Barreca M. Carcinosarcoma and pseudosarcoma of the esophagus: two names, one disease-comprehensive review of the literature. World J Surg. 1999; 23:153-7.

3. Kimura H, Konishi K, Kawamura T, Nojima N, Satou T, Maeda K, et al. Esophageal sarcomas: report of three cases. Dig Surg. 1999;16:244-7.

4. Ziauddin MF, Rodriguez HE, Quiros ED, Connolly MM, Podbielski FJ, et al. Carcinosarcoma of the esophagus_-pattern of recurrence. Dig Surg. 2001;18:216-8.

5. Olmsted WW, Lichtenstein JE, Hyamus VJ. Polypoid epithelial malignancies of the esophagus. AJR Am J Roentgenol. 1983;140:921-5.

\title{
Pulmonary artery ligation with lung preservation in Behcet disease: Report of a case with prolonged survival
}

\author{
Rizwan Attia, MRCS, John Reidy, FRCR, David D’Cruz, FRCP, and Loïc Lang-Lazdunski, MD, PhD, \\ FRCS, London, United Kingdom
}

Rupture of a pulmonary artery (PA) aneurysm remains a leading cause of death in patients with Behcet disease. ${ }^{1}$ We present a case of successful PA ligation and lung preser-

\footnotetext{
From the Department of Thoracic Surgery, Departments of Rheumatology and Radiology, Guy's \& St Thomas' Hospital, London, United Kingdom. Disclosures: None.

Received for publication Oct 20, 2008; revisions received July 1, 2009; accepted for publication July 13, 2009; available ahead of print Sept 11, 2009.

Address for reprints: Loic Lang-Lazdunski, MD, PhD, FRCS, Department of Thoracic Surgery, Guy's Hospital, Great Maze Pond, London SE1 9RT, United Kingdom (E-mail: loic.lang-lazdunski@gstt.nhs.uk).

J Thorac Cardiovasc Surg 2010;139:e93-5

$0022-5223 / \$ 36.00$

Copyright (c) 2010 by The American Association for Thoracic Surgery

doi:10.1016/j.jtcvs.2009.07.033
}

vation with prolonged survival in a patient with Behcet disease and bilateral PA aneurysm.

\section{CLINICAL SUMMARY}

A 36-year-old white man with bilateral PA aneurysms and known Behcet disease had a massive hemoptysis. Medical history included oral and genital ulcerations, pulmonary embolus, left lower lobe infarction, and iliac vein thrombosis after cardiotomy for suspected tricuspid valve endocarditis. The patient was receiving steroids, immunosuppressants, and warfarin. Five months previously, he had coil embolization of an expanding pseudoaneurysm of a basal segmental branch of the right PA, and a covered stent was placed into this arterial branch (Figure 1). 